\title{
ZNACZENIE BAŚNI VON DEM FISCHER UN SYNER FRU (O RYBAKU I JEGO ŻONIE) DLA ZBIORU KINDER- UND HAUSMÄRCHEN BRACI GRIMM I JE PRZEKŁADY NA JĘZYK POLSKI
}

DOl: http://dx.doi.org/10.12775/RP.2017.018

\begin{abstract}
Zarys treści: Baśń Von dem Fischer un syner Fru ma szczególną pozycję w zbiorze baśni braci Grimm Kinder- und Hausmärchen. Autorzy zbioru traktowali tę baśń jak wzorzec stylistyczny i treściowy oraz ucieleśnienie autentycznej baśni ludowej (Volksmärchen). Tymczasem baśń ta za sprawą zabiegów Philippa Ottona Rungego, który jako pierwszy sporządził jej zapis, charakteryzuje się przemyślaną kompozycją ujawniającą cechy baśni literackiej (Kunstmärchen). Wszystkie te elementy każą zapytać o kształt tego tekstu w przekładach na język polski. Analizie translatorskiej, która uwzględnia najważniejsze cechy stylistyczne i treściowe baśni, zostały poddane dwa istniejące przekłady. Wnioski wynikające z tej analizy wiele mówią o dotychczasowej recepcji baśni braci Grimm w Polsce. Aneks do artykułu zawiera krótką charakterystykę trzeciego przekładu baśni, wykonanego poprzez język trzeci - rosyjski.

Słowa kluczowe: baśnie braci Grimm, przekład baśni, seria translatorska
\end{abstract}

\section{Baśń Von dem Fischer un syner Fru jako wzorzec dla zbioru Kinder- und Hausmärchen braci Grimm}

7 apisana w całości dialektem platt baśń pt. Von dem Fischer un syner Fru $\mathbf{L}$ (O rybaku i jego żonie) nie jest tylko jedną z dwustu baśni pomieszczonych w słynnym zbiorze Jakuba i Wilhelma Grimmów Kinder- und Hausmärchen. Jej dzieje dowodzą, że baśń ta miała szczególne znaczenie dla autorów zbioru 
w trakcie ich pracy nad pierwszym wydaniem baśni (1812). Wiele wskazuje na to, że traktowali oni tę opowieść jak swoisty wzorzec baśni ludowej (Volksmärchen), przy zapisywaniu innych fabuł kierowali się bowiem jej przykładem, naśladując m.in. cechy stylistyczne tego tekstu. Jest to o tyle interesujące, że pochodzenie, konstrukcja i problematyka baśni O rybaku i jego żonie sugerują, iż mamy tu raczej do czynienia z tekstem przemyślanym i starannie skomponowanym, bliższym kształtowi baśni literackiej (Kunstmärchen).

\section{1. Źródła i dzieje baśni}

Admiratorem dzieła Clemensa Brentano i Achima von Arnima Des Knaben Wunderhorn był malarz i literat Philipp Otto Runge (1877-1810). Gdy w roku 1805 przeczytał pierwszy tom tego zbioru pieśni ludowych, postanowił odpowiedzieć na wezwanie Arnima, by zbierać wszelakie pieśni, podania, powiedzonka, historie: Lieder, Sagen, Kunden, Sprüche, Geschichten (por. Rölleke 2004: 58). Warto pamiętać, że sami bracia Grimm współpracowali z Brentano i Arnimem przy rzeczonym dziele, a współpraca stała się inspiracją i bezpośrednią przyczyną powstania ich zbioru baśni ${ }^{1}$.

Powróćmy jednak do Rungego, który - jak już wspomniałam - w odpowiedzi na wezwanie Arnima w styczniu 1806 roku przesłał do wydawcy zbioru Heinricha Zimmera dwie baśnie (O drzewie jałowca, O rybaku i jego żonie), zapewniając go w liście, że „starał się je spisać tak, jak je słyszał od piastunek". Zimmer przekazał rękopisy Clemensowi Brentano, który listownie zapewnił potem Rungego, że wykorzysta obydwa teksty w planowanym zbiorze baśni, aczkolwiek utyskiwał na ich gwarowy zapis, utrzymując, iż sam za młodu słyszał te fabuły sformułowane w języku literackim (por. Rölleke 2004: 58).

Ponieważ Brentano ostatecznie nie wydał planowanego zbioru baśni, Arnim poprosił Rungego o zgodę na przedruk obydwu baśni w jego czasopiśmie literackim Zeitung für Einsiedler (por. Martus 2013: 138). W lipcu 1808

${ }^{1}$ Ponieważ jego autorzy, Brentano i von Arnim, planowali kolejną publikację, poświęconą tym razem staroniemieckim baśniom i podaniom, Brentano zachęcił braci, by rozpoczęli zbieranie materiałów. W roku 1810 bracia wysłali Clemensowi Brentano pięćdziesiąt zanotowanych baśni (por. Martus 2013: 203), ale gdy projekt tandemu Brentano/von Arnim nie doszedł do skutku, Achim von Arnim przekonał braci, by opublikowali zebrany materiał pod swoim nazwiskiem (por. Ewers 2012: 38), co - jak pamiętamy - miało miejsce 20 grudnia 1812 roku w Kassel. Dzieło nosiło tytuł Kinder- und Hausmärchen (o źródłach i dziejach powstania zbioru por. PieciulKarmińska 2013a). 
Arnim przedrukował $O$ drzewie jałowca (z wieloma błędami drukarskimi i zmianami), ale czasopismo wkrótce przestało istnieć, więc druga baśń Rungego, O rybaku i jego żonie, już nie ukazała się drukiem. Tematem zainteresowali się jednak bracia Grimm i poprosili Arnima o przekazanie im obydwu baśni w oryginalnym rękopisie Rungego, z którego w roku 1809 Wilhelm Grimm sporządził dokładną kopię (por Rölleke 2011: 157n.).

W odczuciu Grimmów te dwie fabuły były czymś na kształt wzorca (Mustertexte) - w zakresie pochodzenia, formy stylistycznej, motywów i treści. Oferowały wszystko to, co Grimmowie definiowali jako Volksmärchen. Ale decydująca była tu prawdopodobnie gwarowa forma zapisu. Sam Jakub Grimm w liście ze stycznia 1811 roku do Brentano stwierdzil, że nie zna lepszego przykładu „baśni ludowej” od przedrukowanej baśni śp. Rungego o drzewie jałowca, którą wraz z Wilhelmem traktują jak wzorzec wskazujący, czego należy się spodziewać po planowanym przez nich zbiorze baśni (por. Rölleke 2011: 158). O doniosłości wkładu Rungego świadczy też fakt, że jest on jedyną osobą wspomnianą z nazwiska przez Grimmów w ich uwagach (Anmerkungen) do poszczególnych baśni.

Co ciekawe, Brentano w liście do Arnima z początku 1813 roku, odnosząc się do wydanego już zbioru Kinder- und Hausmärchen, ubolewa, że nie wszystkie baśnie są tak dobrze opowiedziane jak obydwa teksty Rungego „doskonałe w swoim gatunku”.

Z kolei Grimmów pociągało w obydwu tekstach Rungego pokrewieństwo ze starymi baśniami zwierzęcymi, co mogło sugerować ich rodowód z tradycji ustnych przekazów. Niezmiernie ważny był także fakt, że obydwa teksty zostały zapisane dialektem ${ }^{2}$, co miało dowodzić dosłowności i wierności zapisu. Tymczasem trudno stwierdzić, na ile wiernie Runge przekazał dialekt: czy sięgał do języka swojego dzieciństwa (pochodził z Wolgast/ Wołogoszczy), czy sam odtwarzał sposób mówienia swojego informatora. Wiadomo natomiast, że Runge lubił opowiadać te baśnie i w trakcie ustnego przekazu nieco modyfikował ich treśćs.

${ }^{2}$ Grimmowie w swej przedmowie do zbioru, expressis verbis żałowali, że nie mogli zapisać wszystkich baśni w zbiorze dialektem.

${ }^{3}$ Reimer, wydawca zbioru KHM, w liście do Wilhelma Grimma z 1 grudnia 1812 roku twierdzi, że Tieck słyszał tę opowieść z ust Rungego w zupełnie innym kształcie (por. Rölleke 2004: 61). Ponadto z zachowanej korespondencji wynika, że Runge sporządził co najmniej cztery różne wersje baśni (por. Rölleke 2011: 158n.). Co ciekawe, sami Grimmowie w roku 1843 (czyli w odniesieniu do V wydania zbioru Kinder- und Hausmärchen) postanowili sięgnąć do wersji zachowanej w zbiorach Daniela Rungego, starszego brata Philippa Ottona. W ten sposób można 
Istotne jest jednak to, że baśni O rybaku i jego żonie nie można traktować jak stenotypu ustnej opowieści, gdyż zdradza ona wiele cech przemyślanej i wręcz doskonałej konstrukcji literackiej.

\subsection{Konstrukcja baśni}

Przyjrzyjmy się zatem kilku płaszczyznom tego utworu, których uporządkowanie i wzajemne powiązania ujawniają konstrukcyjny zamysł Rungego.

\subsubsection{Barwy}

Do fabuły baśni po mistrzowsku włączono całą skalę barw - narastający dramatyzm akcji oznaczają kolejne kolory, co wyraźnie zdradza rękę malarza Rungego ${ }^{4}$. Wręcz sielankowy początek baśni jest oznaczony najjaśniejszym („przezroczystym”) kolorem morskiej wody (blank), która wraz z eskalacją żądań ostatecznie staje się „całkiem czarna” (gans swart). Zmieniające się barwy odzwierciedlają fabułę: woda nabiera coraz bardziej intensywnych i mrocznych kolorów. W baśni mamy więc do czynienia $\mathrm{z}$ następującymi kolorami: przezroczysta woda staje się „żółta i zielona” (gehl und grön), następnie "fioletowa” (vigelett), „szaroczarna” (swart-gru), a na końcu „całkiem czarna” (gans swart). Do tego dochodzi czerwień smugi krwi, ciągnącej się za rybą w wodzie - w ten sposób mamy do czynienia z pełną tęczą (por. Rölleke 2004: 63).

\subsubsection{Czas}

Przemyślana i niezwykle precyzyjna konstrukcja czasowa także sugeruje raczej wpływ artysty i pisarza Rungego aniżeli „ducha ludu” czy oddziaływanie relacji prostego informatora. Ramy czasowe opowieści podzielonej na sześć aktów (sześć życzeń) wyglądają następująco: po spełnieniu pierwszego życzenia rybak z żoną przebywa w nowym domu około dwóch tygodni. Spełnienie

założyć, że istnieją dwie równoprawne wersje baśni - wersja z wydań pomiędzy 1812 a 1840 rokiem oraz druga wersja, obecna w wydaniach z lat 1843-1857.

${ }^{4}$ Dostrzec tu można nie tylko rękę malarza. Runge był artystą, ale również teoretykiem sztuki malarskiej. W 1810 roku opublikował swoją teorię barw (Die Farbkugel), w której zaprezentował pierwszy trójwymiarowy model skali barw. 
drugiego życzenia (zamek) pociąga za sobą okres jednej nocy, a trzecie życzenie (zgodnie z proporcjonalnym redukowaniem czasu) cieszy żonę rybaka już tylko krótką chwilę. Od tego miejsca, które jest równocześnie punktem przejścia od życzeń dotyczących sfery materialnej do życzeń dotyczących sfery władzy i panowania, zaczyna się wyraźny zwrot akcji i druga triada życzeń, która postępuje w odwrotnym porządku czasowym: na pozycji cesarza (czwarte życzenie) żona wytrzymuje krótką chwilę. Spełnienie piątego życzenia (a środkowego w triadzie) gwarantuje - jak w lustrzanym odbiciu - jedną noc na papieskim stolcu, aż pojawia się trzecie życzenie, które burzy powstały porządek i powoduje restitutio ad integrum, powrót do punktu wyjścia. Opowieść zatacza krąg.

\subsubsection{Miejsca i życzenia}

Sześciu kolorom odpowiada sześć życzeń (w określonym chronologicznym porządku), a sześciu życzeniom odpowiada sześć lokalizacji (lepianka, dom, zamek, pałac króla, pałac cesarza, pałac papieża), które podobnie jak ramy czasowe można podzielić na dwie triady (pierwsza triada jest materialna, gdyż obejmuje zwykłe miejsca zamieszkania; druga triada ma znaczenie symboliczne - kolejne budynki oznaczają władzę).

Wprawdzie trojaka struktura jest charakterystyczna dla baśni ludowej, ale równoległe prowadzenie dwóch triad jasno zdradza artystyczny wpływ Rungego, który po mistrzowsku wykorzystał i przetworzył ten element stylistyczny.

W poniższej tabeli zestawiono owe trzy kluczowe elementy opowieści (miejsce, czas i wypowiadane przez żonę rybaka życzenia), dzięki czemu widać ich wzajemne powiązania i precyzyjną konstrukcję tekstu.

\begin{tabular}{|l|l|l|l|}
\hline & \multicolumn{1}{|c|}{ miejsca } & \multicolumn{1}{c|}{ życzenia } & \multicolumn{1}{c|}{ czas } \\
\hline \multirow{3}{*}{$\begin{array}{l}\text { posiadanie - dobra } \\
\text { materialne }\end{array}$} & 1. lepianka & & \\
\cline { 2 - 4 } & 2. nowy dom & 1. nowy dom & 2 tygodnie \\
\cline { 2 - 4 } & 3. zamek z kamienia & 2. zamek z kamienia & 1 noc \\
\hline \multirow{4}{*}{ władza - panowanie } & 1. pałac królewski & 3. król & 1 chwila \\
\cline { 2 - 5 } & 2. pałac cesarski & 1. cesarz & 1 chwila \\
\cline { 2 - 5 } & 3. pałac papieski & 2. papiė & 1 noc \\
\cline { 2 - 5 } & & 3. jak Bóg & do dzisiaj \\
\hline
\end{tabular}




\subsection{Warstwa językowa baśni jako miara stylistyczna dla zbioru Kinder- und Hausmärchen}

Z kolei analiza elementów stylistycznych tekstu Rungego jasno dowodzi, jak wskazuje na to Rölleke (2004: 64nn.), że w omawianej baśni można rozpoznać określony zespół cech, które stały się wzorcem dla innych fabuł w zbiorze Grimmów. Szczególnie istotne są w tym kontekście następujące elementy:

- zamiłowanie do zdań pojedynczych i współrzędnie złożonych, połączonych za pomocą und i da (naśladujących styl ustnej opowieści);

- potęgowanie nastroju i dramatyzmu przez powtórzenie słów ${ }^{5}$;

- formuła otwierająca (Es war einmal...) i zamykająca (...noch heute);

- prosta konstrukcja epicka (na scenie tylko dwie osoby);

- stosowanie mowy niezależnej (dialogi);

- skłonność do groteski (Ilsebill jako papież w łóżku małżeńskim);

- oczywistość, z jaką bohaterowie przyjmują wydarzające się cuda;

- używanie rymowanych formuł - powtarzanych na każdym kolejnym etapie fabuły.

Sami Grimmowie uznali tę baśń za miarę i swoisty wzorzec dla wszelkich innych baśni, starając się podążać za tym ideałem i komponując z przekazanych im opowieści podobne fabuły o analogicznej strukturze.

\subsection{Doniosłość i wpływ baśni}

Jeśli przyjrzymy się treści baśni, zauważamy, iż tekst ten wyróżnia szczególnie doniosłe przesłanie. Jest to bowiem ni mniej, ni więcej starotestamentowa opowieść o upadku w grzech Adama i Ewy. Ostatnie życzenie Ilsebill zawiera dosłowne powtórzenie słów węża $\mathrm{z}$ Księgi Rodzaju, który przekonuje Ewę do zjedzenia jabłka: „Ale wie Bóg, że gdy spożyjecie owoc z tego drzewa, otworzą się wam oczy i tak jak Bóg będziecie znali dobro i zło" (Rdz 3,5; Biblia Tysiaclecia). Ilsebill pragnie być ,jak Bóg” i tak samo jak Ewa zostaje za to pragnienie wygnana $\mathrm{z}$ raju wraz z mężem.

${ }^{5}$ Widać to od razu w pierwszych zdaniach baśni: „... un de Fischer güng alle Dage hen un angeld: un he angeld un angeld. So seet he ook eens by de Angel un seeg jümmer in dat blanke Water henin: un he seet un seet." (Grimm 1857: 100). Tarnowski w swoim przekładzie redukuje połowę powtórzeń i pisze: „Co dzień siadał rybak na brzegu, zapuszczał wędkę i łowił, a łowił” (Grimm 1982: 104). W moim przekładzie: „... rybak codziennie wychodził łowić - łowił i łowił. I tak siedział raz ze swą wędką i wpatrywał się w przejrzystą wodę - siedział i siedział" (Grimm 2010: 106). 
Baśń ta jest jednocześnie na tyle wielowarstwowa, że można ją odczytywać nie tylko teologicznie. Na poziomie mitologicznym pobrzmiewa tu mit o Semele, na poziomie literackim jawi się postać papieżycy Joanny. Natomiast w znaczeniu politycznym już w roku 1814 traktowano ten tekst jako aluzję do upadku Napoleona, a w roku 1945 - do upadku Hitlera. Nadal odczytywany jest w różnych paradygmatach - psychologicznie, antropozoficznie czy feministycznie, a współcześnie najmocniej nawiązał do tej baśni Günter Grass w swojej powieści Der Butt (1977), w której - jak sam informuje - opisuje tę właśnie fabułę:

W rzeczy samej będę na tych kartkach przypominał to, co Philipp Otto Runge spisał jako drugą prawdę; choćbym miał słowo po słowie odczytywać z popiołu. Bo dodatkowo podyktowana malarzowi latem roku 1805 gadka starej niewiasty została spalona między sarnią polaną a leśnym stawem przy księżycu w pełni. Tym sposobem panowie chcieli chronić patriarchalny porządek. To dlatego bracia Grimm wprowadzili na baśniowy rynek tylko jeden rugijski zapis historii „O rybaku i jego żonie”. Od tej pory żona rybaka, Ilsebill, jest postacią przysłowiową: kłótliwe babsko, które chce coraz więcej mieć, posiadać, opanować. (...) Wciąż jej mało. Wciąż ma jeszcze jakąś zachciankę. Taka jest książkowa Ilsebill (Grass 1995: 42).

\section{Polskie przekłady}

Z powyższego wstępu wynika, że baśń O rybaku i jego żonie zajmuje ważne miejsce w dziejach literatury niemieckiej i szerzej - w kulturze obszaru niemieckojęzycznego. Fakt, iż Grimmowie traktowali ją jak szczególny „wzorzec metra z Sevres”, a na jej obraz i podobieństwo komponowali zgromadzone przez siebie fabuły, każe nam zapytać o kształt tej baśni w języku polskim.

Pytanie translatoryczne brzmi więc: na ile powyżej wyszczególnione cechy stylistyczne, kompozycyjne, treściowe i konstytucyjne, właściwe dla tekstu baśni (i całego zbioru KHM), są rozpoznawalne w polskich przekładach tej baśni.

Już wstępna obserwacja liczby polskich przekładów jasno ukazuje, że w Polsce baśń ta nie cieszy się porównywalnym bądź choćby przybliżonym prestiżem. Oczywiście wszyscy znamy opowieść o rybaku, który złowił rybę spełniającą jego życzenia - jest ona wydawana w licznych adaptacjach zwykle pod tytułem O rybaku i złotej rybce, co - najprawdopodobniej - odbywa się pod wpływem literackiej parafrazy Aleksandra Puszkina w przekładzie Julia- 
na Tuwima ${ }^{6}$, w której rybak wyciąga z morza złotą rybkę (por. Puszkin 1979). Taki kształt tytułu w oczywisty sposób przesuwa akcenty: punktem ciężkości baśni w takich adaptacjach nie jest już tylko radykalna krytyka niepohamowanego apetytu żony rybaka, lecz również sam fakt spotkania magicznej złotej rybki spełniającej życzenia.

Jednakże jeśli chodzi o rzeczywisty przekład, czyli tłumaczenie oryginalnej baśni pomieszczonej w wydaniu z roku 1857, to w języku polskim mamy do czynienia raptem z dwoma takimi przedsięwzięciami - Marcelego Tarnowskiego (Grimm 1982) i autorki niniejszego tekstu (Grimm 2010).

Charakterystyczna jest także stosunkowo późna polska premiera wiernego przekładu tej baśni (170 lat po premierze niemieckiej). Przekład Marcelego Tarnowskiego, chociaż sporządzony przed II wojną światową, nie został uwzględniony w najważniejszym (a przez dziesięciolecia jedynym) powojennym wydaniu baśni pod redakcją Stefanii Wortman z 1956 roku. Wersja Tarnowskiego została opublikowana dopiero w roku $1982 \mathrm{w}$ pierwszym pełnym wydaniu baśni braci Grimm (Baśnie domowe i dziecięce).

Drugi polskojęzyczny przekład O rybaku i jego żonie pojawił się najpierw w roku 2009 (Baśnie), a następnie w roku $2010 \mathrm{w}$ ramach drugiego pełnego polskojęzycznego wydania zbioru baśni braci Grimm (Baśnie dla dzieci i dla dотu $)^{7}$.

Można założyć, że dzięki analizie baśni O rybaku i jego żonie, konstytutywnej dla oryginalnej koncepcji zbioru Kinder- und Hausmärchen, zobaczylibyśmy jak w soczewce, czy i jak w polskim przekładzie rozpoznano i zrealizowano elementy tekstu uznane przez Grimmów za miarę i wzorzec ich koncepcji baśni. Taka analiza na poziomie szczegółu może przynieść istotne rozpoznania dotyczące całościowej recepcji baśni Grimmów w Polsce, która - jak słusznie wielokrotnie podkreślała Maria Krysztofiak $(1999,2011)$ sprzeniewierza się oryginalnemu zamiarowi zbioru.

Niniejsza analiza jest $\mathrm{z}$ oczywistych powodów wybiórcza ${ }^{8}$ i stanowi punkt wyjścia do bardziej pogłębionych badań. Odniosę się do najbardziej

${ }^{6} \mathrm{Na}$ osobną analizę zasługuje wpływ tekstu Puszkina na polskie adaptacje, które jakoby odwołują się do baśni Grimmów.

7 W roku 2012 pojawiło się kolejne pełne wydanie zbioru (wraz z interesującą nas baśnią), ale traktuję je jak odrębny przypadek, gdyż zbiór ten został przetłumaczony z języka rosyjskiego. Ten punkt widzenia uzasadniam w osobnej publikacji (por. Pieciul-Karmińska 2013b), o czym więcej w Post scriptum do niniejszego tekstu.

${ }^{8}$ Przykładowo warto byłoby zbadać elementy groteski. Fragment opisujący szał żony w wiernym przekładzie: „Na to żona wpadła we wściekłość, potargała sobie włosy, zerwała 
charakterystycznych elementów tekstu, które każdorazowo zestawię w tabeli w następującym porządku: 1) cytat $\mathrm{z}$ oryginału (Grimm 1857), 2) cytat z przekładu Marcelego Tarnowskiego (Grimm 1982) i 3) cytat z przekładu Elizy Pieciul-Karmińskiej (Grimm 2010).

\subsection{Der Butt - złota rybka - turbot}

Pierwszym problemem, który należy omówić, jest pytanie o gatunek ryby wyłowionej $\mathrm{z}$ morza, która $\mathrm{w}$ rozlicznych polskich adaptacjach jest nieodmiennie „złotą rybką," a to z kolei zyskuje wyraz w zmianie oryginalnego tytułu (O rybaku i złotej rybce). Jaki gatunek ryby pojawia się w omawianych przekładach, pokazuje poniższa tabela.

\begin{tabular}{|c|c|c|}
\hline Grimm (1857) & Grimm (1982) & Grimm (2010) \\
\hline $\begin{array}{l}\text {...so haald he enen grooten } \\
\text { Butt heruut. (100) }\end{array}$ & $\begin{array}{l}\text {... a kiedy ją wyciągnął, } \\
\text { ujrzał dużą złotą rybkę... } \\
\text { (105) }\end{array}$ & $\begin{array}{l}\text {... wyciągnął z wody potęż- } \\
\text { nego turbota. (107) }\end{array}$ \\
\hline
\end{tabular}

Wprawdzie tytuł baśni w przekładzie Tarnowskiego podąża za tytułem oryginału (O rybaku i jego żonie), ale do tekstu w kluczowym momencie mimo wszystko zostaje wprowadzona (Puszkinowska?) złota rybka i to z epitetem, który tworzy niezamierzony oksymoron, bo oto mamy do czynienia $\mathrm{z}$ „dużą" złotą rybką. W dalszej części narracji i dialogach tłumacz używa zwykle określenia „rybka” (aczkolwiek kilkakrotnie mówi też o „rybie”), co z kolei tworzy niezamierzony dysonans między pieszczotliwym zdrobnieniem a faktyczną rangą zwierzęcego demiurga, który potrafi uczynić żonę rybaka papieżem i wywołać wręcz apokaliptyczny potop.

$\mathrm{W}$ drugim omawianym przekładzie pojawia się - zgodnie z oryginałem - turbot ${ }^{9}$. Ten wierny i zrywający z utrwaloną tradycją przekład ma wiele zalet: po pierwsze, zachowuje zgodność płci - baśń mówi bowiem, że turbot to

z siebie koszulę nocną i kopnęła męża: - Nie wytrzymam tego! Już tego więcej nie wytrzymam. Natychmiast ruszaj w drogę! Rybak wciągnął spodnie i nie czekając dłużej wybiegł.” (Grimm 2010: 116). W przekładzie Tarnowskiego tych elementów brakuje: „Wtedy kobieta wpadła w wielką wściekłość, oczy jej pałały, włosy stanęły dęba wokoło głowy, zerwała się i krzyknęła: - W tej chwili mi się stąd wynoś i nie waż się nie spełnić mojego rozkazu! Rybak ubrał się i pognał w stronę morza jak szalony" (Grimm 1982: 112).

${ }^{9} \mathrm{~W}$ przekładzie angielskim mamy w tym miejscu określenie the flounder (taki sam tytuł nosi angielski przekład powieści Grassa). 
zaczarowany książę. Ponadto ów książę posiada potężną moc: spełnia coraz bardziej wymyślne życzenia żony rybaka oraz panuje nad naturą, wywołując groźne morskie nawałnice. Tymczasem „złota rybka” przywodzi na myśl odmienne skojarzenia: miłego, bajkowego stworzenia jak z filmów Disneya. Również wiedza o tym, że baśń wywodzi się z wybrzeża Morza Bałtyckiego, każe skrytykować przekład, w którym z Bałtyku rybak jest w stanie wyłowić egzotyczną złotą rybkę rodem $\mathrm{z}$ ciepłych mórz południowych.

Ale obecność turbota w polskim przekładzie ma jeszcze jeden wymiar, o wiele ważniejszy. Dla polskiego czytelnika wychowanego na złotej rybce intertekstualne nawiązanie obecne w powieści Turbot pozostanie całkowicie nieczytelne. Szczególnie, że w powieści Grassa turbot posiada moc analogiczną do potęgi zaklętego księcia z baśni Grimmów. Zyskuje on rangę demiurga i jak pisze Maria Janion we wstępie do polskiego wydania powieści, wciela się on „w wiele boskich postaci: heglowskiego Ducha Świata czy niszczącej, męskiej, wojowniczej zasady. Nazywany był "męskim Superego" (Janion 1995: 19). Nasza polska „złota rybka”, również ze względu na różnicę płci, nie mogłaby reprezentować owego bosko-męskiego pierwiastka.

\subsection{Imię żony: Ilsebill}

W powieści noblisty pojawia się nie tylko tytułowy turbot, lecz również narrator-mężczyzna i jego żona Ilsebill. Tego nawiązania czytelnik polski nie rozpozna, gdyż w przekładzie Tarnowskiego żona rybaka była bezimienna. Tymczasem w oryginale poznajemy jej imię w wierszyku, którym rybak wzywa turbota. Warto przy okazji podkreślić, że w baśniach braci Grimm niezwykle rzadko poznajemy imiona bohaterów, a jeśli nawet, to są to zwykle przydomki lub przezwiska (vide Kopciuszek czy Czerwony Kapturek), więc jeśli mamy do czynienia $\mathrm{z}$ tekstem, w którym bohater zostaje nazwany z imienia, to jest to cecha, której nie można ignorować w przekładzie.

\begin{tabular}{|c|c|c|}
\hline Grimm (1857) & Grimm (1982) & Grimm (2010) \\
\hline $\begin{array}{l}\text { Manntje, Manntje, Timpe Te, } \\
\text { Buttje, Buttje in der See, } \\
\text { Myne Frau, de Ilsebill, } \\
\text { Will nich so, as ik wol will. } \\
\text { (101) }\end{array}$ & $\begin{array}{l}\text { Złota rybko, złota rybko, } \\
\text { Usłysz, usłysz me wołanie, } \\
\text { Żona moja mnie przysyła, } \\
\text { Byś spełniła jej żądanie! } \\
(105)\end{array}$ & $\begin{array}{l}\text { Cny turbocie, jakich mało, } \\
\text { mojej żonie Ilsebill } \\
\text { w głowie się poprzewracało, } \\
\text { przybądź tu na kilka chwil! } \\
(107)\end{array}$ \\
\hline
\end{tabular}

Cytowane powyżej wierszowane wezwanie rybaka, w którym woła on turbota (Buttje), a jednocześnie przekazuje dwie istotne informacje: o życze- 
niu żony Ilsebill oraz swoim zdystansowaniu się od tego życzenia, jest jednym z bardziej znanych rymowanek z baśni braci Grimm. Grass właśnie te rymy przywołuje jako koronny dowód na to, że rzeczona baśn „po dziś dzień” pozostaje źródłem cytatów:

On, turbot, nic na to nie może poradzić, że ścisły historycznie zapis malarza został przez braci Jakuba i Wilhelma Grimmów w obecności poetów Arnima i Brentano strachliwie spalony. Tym samym jedynie jego legenda trafiła do popularnego zbioru „Baśni domowych i dziecięcych”. Bądź co bądź ludowa bajka po dziś dzień pozostała źródłem cytatów. Turbot z miejsca podał przykład: „Ilsebilla, żona moja, nie chce tego, czego chcę ja" (Grass 1993: 62).

Oczywiście tłumacz Grassa przekłada tekst za oryginałem (w miarę dosłownie i nie siląc się na zachowanie rytmu ani precyzyjnych rymów): „Ilsebilla, żona moja, nie chce tego, czego chcę ja". Dla polskiego czytelnika ten tekst jest martwy: bo nie zna on oryginału, a znana mu wcześniej wersja zawierała zupełnie inną treść. W przekładzie Tarnowskiego pojawia się mianowicie „złota rybka”, nie pojawia się imię żony „Ilsebill” oraz nie ma informacji, że rybak dystansuje się od swojej żony. Tym sposobem wszystkie trzy konstytutywne elementy zostały zniwelowane.

W drugim przekładzie ponownie postulat wierności sprawił, że w wierszyku znajduje się turbot zamiast złotej rybki oraz pojawia się imię żony rybaka: Ilsebill. Dodatkową informacją, nieobecną we wcześniejszym przekładzie, jest wyraźne zdystansowanie się rybaka od kolejnych życzeń żony. Wierny przekład nie pozbawia więc polskiego czytelnika wiedzy, jaką posiada odbiorca oryginału. Znając prawdziwe wcielenie zaczarowanego księcia oraz imię żony rybaka, będzie on mógł bez trudu rozpoznać aluzje w powieści Grassa. Na marginesie trzeba oczywiście wspomnieć, że przekład tego wierszyka jest ograniczony przez obecność gwary, bo jak znaleźć polski odpowiednik dla wyliczanki: Manntje, Manntje, Timpe Te?

\subsection{Barwy}

Jak w polskich przekładach zostały odtworzone omówione wyżej elementy kompozycyjne tekstu (por. 1.2)? Obydwa tłumaczenia zarówno w odniesieniu do czasu, jak i miejsca akcji wiernie odtwarzają zamysł oryginału i zawierają wszystkie niezbędne części konstrukcji.

Na szczególną uwagę zasługuje jednak kwestia barw, gdyż pieczołowicie skomponowana skala kolorów, współgrająca z narastającym dramaty- 
zmem akcji, w przekładzie Tarnowskiego została nierozpoznana. Mamy tu do czynienia z niekonsekwentnym przekładem, w którym de facto tylko połowa kolorów znalazła swoje docelowe odpowiedniki, co ilustruje poniższa tabela.

\begin{tabular}{|c|c|c|}
\hline Grimm (1857) & Grimm (1982) & Grimm (2010) \\
\hline Blank & $\begin{array}{l}\text {..wpatrując się w przezro- } \\
\text { czystą wodę... } \\
\text {..wpuścił rybkę do wody... } \\
\text { (105) }\end{array}$ & $\begin{array}{l}\text {...wpatrywał się w przejrzy- } \\
\text { stą wodę... (106) } \\
\text {..włożył ją z powrotem do } \\
\text { przejrzystej wody (107) }\end{array}$ \\
\hline gehl und grön & $\begin{array}{l}\text {..udał się jednak na brzeg } \\
\text { morza, które było teraz po- } \\
\text { ciemniałe i zamącone... } \\
(105)\end{array}$ & $\begin{array}{l}\text {...morze było zielonożółte } \\
(107)\end{array}$ \\
\hline vigelett & $\begin{array}{l}\text { Tym razem woda była jesz- } \\
\text { cze ciemniejsza i mętniej- } \\
\text { sza... (107) }\end{array}$ & $\begin{array}{l}\text {...woda nie była już zielono- } \\
\text { źółta. Była fioletowograna- } \\
\text { towa... (109) }\end{array}$ \\
\hline swart-gru & $\begin{array}{l}\text {...szarawoczarne fale... } \\
(108)\end{array}$ & $\begin{array}{l}\text { woda była ciemnoszara... } \\
(110)\end{array}$ \\
\hline gans swart & $\begin{array}{l}\text {...morze }(\ldots) \text { było wzburzo- } \\
\text { ne i zupełnie czarne... (110) }\end{array}$ & $\begin{array}{l}\text {...morze }(\ldots) \text { było całkiem } \\
\text { czarne... (112) }\end{array}$ \\
\hline
\end{tabular}

Można założyć, że tłumacz starszego przekładu nie rozpoznał zamysłu artystycznego kryjącego się za doborem przymiotników, a być może uznał, iż zastosowane określenia stanu i koloru wody morskiej są nielogiczne (dotyczy to zredukowanych barw: żółtej, zielonej, fioletowej) i postanowił poprawić tekst zgodnie z zasadą „ulogicznienia” (niem. Logisierung) opisaną przez Schreibera (1993: 268), w ramach której tłumacz usuwa (rzekome w tym przypadku) błędy logiczne.

Tarnowski najwyraźniej przyjął właśnie taką metodę, gdyż w miejsce uznanych za nielogiczne kolorów wprowadził określenia, które opisują wygląd wody bez odwoływania się do skali barw: morze najpierw jest przezroczyste, potem staje się „pociemniałe i zamącone”, następnie „ciemniejsze i mętniejsze”, a na koniec „szarawoczarne” i „zupełnie czarne”. Nawet użycie dwóch ostatnich określeń w całym kontekście nie tyle odsyła do skojarzeń z kolorami, co do rozróżnienia między „jasno - ciemno”, a jak wiemy, nie to było zamysłem tekstu.

Także w tym przypadku najprostszym rozwiązaniem było wierne (wręcz dosłowne) podążanie za tekstem, gwarantujące restytucję oryginalnej intencji. 


\subsection{Aluzja do Księgi Rodzaju (3,5): „być jak Bóg”}

Ostatnim elementem, który chciałabym zreferować, jest element treściowy nawiązanie do Księgi Rodzaju $(3,5)$ i słów o pragnieniu, by być „jak Bóg”. Jak już wspomniałam, sformułowanie to jest kluczowe dla głębszego odczytania baśni, a równocześnie stanowi punkt kulminacyjny narracji.

\begin{tabular}{|c|c|c|}
\hline Grimm (1857) & Grimm (1982) & Grimm (2010) \\
\hline $\begin{array}{l}\text { "Na, wat will se denn?" } \\
\text { säd de Butt. „Ach,“ säd he, } \\
\text { "se will warden as de lewe } \\
\text { Gott." (108) }\end{array}$ & $\begin{array}{l}\text { - No, a czegóż ona teraz } \\
\text { chce? - zapytała rybka. } \\
\text { - Ach - jęknął rybak - chce } \\
\text { być samym Panem Bogiem. } \\
\text { (113) }\end{array}$ & $\begin{array}{l}\text { - I czego teraz chce? - zapy- } \\
\text { tał turbot. } \\
\text { - Ach - odpowiedział rybak } \\
\text { - chce być jak dobry Bóg. } \\
\text { (116) }\end{array}$ \\
\hline
\end{tabular}

Błąd obecny w przekładzie Tarnowskiego jest być może wynikiem niedopatrzenia, ale oczywiście sygnalizuje nierozpoznanie istotnego elementu ideologii tekstu. Równocześnie jego skutki są dość poważne: tekst nie tylko traci swoją biblijną wymowę (a jednocześnie klucz do odczytania całej opowieści), lecz dodatkowo zyskuje komiczny wręcz wymiar: żona nie tyle popełnia grzech pierworodny (którym, jak pamiętamy, jest ludzka pycha), co najwyraźniej ulega chorobliwej manii wielkości („chce być samym Panem Bogiem”). To oczywiste przeinaczenie niszczy całą sieć odczytań oraz późniejszych nawiązań ${ }^{10}$.

Ten błąd Tarnowski popełnia już we wcześniejszym fragmencie baśni: „Ach, żono (...), tego ryba już nie potrafi zrobić, papieża mogła jeszcze z ciebie zrobić, ale Boga to już na pewno nie; błagam cię, zostań tym, czym jesteś” (Grimm 1982: 112). Co ciekawe, w oryginale w ramach tej wypowiedzi rybaka nie ma odniesienia do Boga, a tylko do cesarza i papieża:

„Ach, Fru, “säd de Mann, un füll vör eer up de Knee, „dat kann de Butt nich. Kaiser un Paabst kann he maken, ik bidd dy, sla in dy un blyf Paabst." (Grimm 1857: 108) [Ach, żono (...), turbot tego nie potrafi. Umie zrobić cesarza i papieża. Proszę cię, bądź rozsądna i pozostań papieżem! (Grimm 2010: 116)].

${ }^{10}$ Błąd Tarnowskiego powtarza Maria Janion w przedmowie do Turbota: „Chce ona kolejno być królem, cesarzem, papieżem - i tak się staje, a wreszcie Panem Bogiem. Tego ostatniego życzenia turbot już nie mógł znieść” (Janion 1995: 10). Aczkolwiek Błaut Turbota tłumaczy poprawnie: „w końcu jednak, jako że życzy sobie od wszechmocnego turbota bycia jako Bóg - »Chcę mieć władzę jak sam Pan Bóg« - zostaje przeniesiona z powrotem do swej krytej słomą chaty” (Grass 1995: 349). Wydaje się więc, że prof. Janion opierała się w swoich rozważaniach na tekście Tarnowskiego. 
Tłumacz nie tylko dopisuje zatem błędny fragment, ale i ujawnia niezrozumienie intencji i symboliki tekstu. W takim ujęciu bowiem owa złota rybka musiałaby być jakimś „,nadbogiem”, który jest w stanie uczynić z żony rybaka samego Boga wszechmogącego.

\section{Wnioski}

Wiemy już, że baśń O rybaku i jego żonie nie jest po prostu jedną z dwustu baśni ze zbioru Kinder- und Hausmärchen, lecz że wraz z baśnią $O$ drzewie jałowca stanowiła wzorzec i miarę używaną w pracy redakcyjnej i kompozycyjnej Grimmów. Jej swoiste cechy, opisane powyżej, stały się inspiracją i punktem wyjścia do tworzenia analogicznych fabuł z otrzymanych od informatorów opowieści.

W takiej sytuacji prześledzenie sposobu jej przekładu na język polski pozwala precyzyjnie zarysować potencjalne źródła trudności dla polskich tłumaczy baśni braci Grimm, a w ostatecznym rozrachunku zobrazować skutki opisywanych przeinaczeń i to nie tylko dla docelowej recepcji tekstu baśni, lecz przede wszystkim dla możliwości włączenia się w międzykulturowy dia$\log$ i odczytanie intertekstualności.

Równocześnie prześledzenie odnotowanych odstępstw od pierwotnej intencji tekstu jasno dowodzi, że (nie)wierność na poziomie kodu leksykalno-semantycznego i kodu kulturowego (zgodnie z koncepcją Krysztofiak, por. 1999: 71nn.) ostatecznie rzutuje na (nie)możliwość odtworzenia kodu estetycznego ${ }^{11}$. W wyniku pozornie drobnych modyfikacji i zaniedbań w języku docelowym powstaje tekst, który w dogłębny sposób sprzeniewierza się zamiarowi oryginału. Wielowarstwowość oryginału, obecność motywów biblijnych i mitologicznych, swoisty obraz świata odzwierciedlający porządek i hierarchię społeczną (vide męskie role żony rybaka), szczególna rola zwierzęcego demiurga-turbota - wszystko to bezpowrotnie znika lub zostaje spłycone w przekładach ignorujących kod estetyczny tekstu. Nic dziwnego, że w powszechnej świadomości czytelników polskich ta baśń nie zajmuje należnego jej miejsca, a z pewnością - na podstawie „kanonicznego” przekładu Tarnowskiego czy popularnych adaptacji - nie można by się domyślić, iż był to tekst konstytutywny dla zbioru Grimmów.

11 Także Staniów zwraca uwagę, iż większość polskich tłumaczeń baśni braci Grimm całkowicie sprzeniewierza się oryginalnemu: treściowemu i stylistycznemu zamysłowi (por. Staniów 2014: 17). 


\section{Post scriptum - przypadek szczególny: tłumacz wobec dokonań innych tłumaczy}

W 2012 roku w wydawnictwie REA pojawiło się wydanie Wszystkich baśni i legend braci Grimm, które zostało sporządzone w oparciu o dziewiętnastowieczny przekład rosyjski. Wydanie to jest obarczone dużą liczbą błędów. Opisałam je szczegółowo w artykule pt.: „»Niebieska broda«”, czyli dlaczego nie należy tłumaczyć baśni braci Grimm z języka rosyjskiego” (Pieciul-Karmińska 2013b), który wysłałam także redakcji wydawnictwa REA. W drugim wydaniu Wszystkich baśni i legend z roku 2014 redaktorzy tomu nie tylko poprawili wskazane przeze mnie błędy, lecz również zdecydowali się na wprowadzenie niezbędnych przypisów wyjaśniających kontekst powstania rosyjskiej wersji baśni, która stała się podstawą tłumaczenia polskiego (por. Grimm 2014: 3).

$\mathrm{W}$ omawianym artykule zawarłam również krytyczne uwagi dotyczące trzech głównych przeinaczeń obecnych w przekładzie baśni O rybaku i jego żonie (por. Pieciul-Karmińska 2013b: 72): złotej rybki, żeńskich (zamiast męskich) tytułów, jakich życzyła sobie żona rybaka ${ }^{12}$, oraz ostatniego życzenia żony, by „być Bogiem” (por. Grimm 2012: 128).

Z poniższych zestawień wynika, że redaktor drugiego poprawionego wydania Wszystkich baśni i legend wziął sobie do serca krytykę „złotej rybki” czy kwestii ostatniego życzenia żony. Zmieniono także nieuprawnione formy żeńskie (królowa, cesarzowa) na formy zgodne z oryginałem (król, cesarz) ${ }^{13}$. Przykład ten może być poglądowym przyczynkiem do dyskusji na temat: „tłumacz wobec dokonań innych tłumaczy”.

12 „Jednak niezgodne $\mathrm{z}$ oryginałem jest również tłumaczenie kolejnych próśb żony rybaka, która chciała być jakoby »królową« i »cesarzową" (Grimm 2012: 125n.), podczas gdy w oryginale żona rybaka jednoznacznie życzyła sobie ról męskich (König, Kaiser, por. Grimm 1857: 104n.), i chociaż w języku polskim (a także w rosyjskim) niezgodność rodzaju nie brzmi szczęśliwie: »I co, kobieto, jesteś teraz królem?«/»Ach żono, do twarzy ci być królem!«/»Ależ żono (...) na co ci być cesarzem?« (Grimm 2010: t. I, 111), to jednak ważniejsza od poprawności powinna tu być wierność oryginałowi (żona rybaka, pragnąc władzy, słusznie domagała się ról męskich, bo tylko one oznaczały realną władzę)” (Pieciul-Karmińska 2013b: 72).

13 Ponieważ jednak w artykule nie odniosłam się do innych kwestii - w tym także problematyki barw, to w obydwu wydaniach Wszystkich baśni i legend barwy morza są pomijane i zlekceważone: „wpatrywał się w błyszczącą wodę” (Grimm 2012: 120; 2014: 120), „morze już pociemniało i fale nie błyszczały tak jak rano" (Grimm 2012: 121; 2014: 121). 


\begin{tabular}{|c|c|c|}
\hline & Grimm (2012) & Grimm (2014) \\
\hline \multirow[t]{2}{*}{ złota rybka - turbot } & $\begin{array}{l}\text { Kiedy wreszcie udało mu się } \\
\text { wyciągnąć wędkę na brzeg, } \\
\text { okazało się, że była to złota } \\
\text { rybka. (120) }\end{array}$ & $\begin{array}{l}\text { Kiedy wreszcie udało mu się } \\
\text { wyciągnąc wędkę na brzeg, } \\
\text { okazało się, że był to wspa- } \\
\text { niały turbot. (120) }\end{array}$ \\
\hline & $\begin{array}{l}\text { Rybo, rybko, rybeńko, } \\
\text { złota rybko, serdeńko, } \\
\text { choć się nie zgadzałem, żona } \\
\text { przysłała mnie, aby prośba } \\
\text { została spełniona. (122) }\end{array}$ & $\begin{array}{l}\text { Rybo, rybko, rybeńko, } \\
\text { turbocie miły, serdeńko, } \\
\text { choć się nie zgadzałem, żona } \\
\text { przysłała mnie, aby prośba } \\
\text { została spełniona. (122) }\end{array}$ \\
\hline \multirow[t]{2}{*}{$\begin{array}{l}\text { formy żeńskie versus formy } \\
\text { męskie }\end{array}$} & $\begin{array}{l}\text { To, że ty nie możesz być kró- } \\
\text { lem, nie oznacza, iż ja nie } \\
\text { nadaję się na królową. Idź do } \\
\text { ryby, powiedz jej, że chcę być } \\
\text { królową! (124) }\end{array}$ & $\begin{array}{l}\text { Dobrze więc, nie musisz być } \\
\text { królem, ale to nie oznacza, } \\
\text { że ja nie mogę nim zostać! } \\
\text { Idź natychmiast do turbo- } \\
\text { ta i powiedz jej, że chcę być } \\
\text { królem! (124) }\end{array}$ \\
\hline & $\begin{array}{l}\text { Idź powiedz rybce, że już nie } \\
\text { chcę być królową, tylko cesa- } \\
\text { rzową. (125) }\end{array}$ & $\begin{array}{l}\text { Idź powiedz turbotowi, że } \\
\text { teraz chcę być cesarzem. } \\
(125)\end{array}$ \\
\hline \multirow[t]{2}{*}{ być Bogiem - być jak Bóg } & $\begin{array}{l}\text { Natychmiast idź do rybki! } \\
\text { Chcę być Bogiem! (128) }\end{array}$ & $\begin{array}{l}\text { Natychmiast idź do ryby! } \\
\text { Chcę być jak dobry Bóg! }\end{array}$ \\
\hline & $\begin{array}{l}\text { Ach - wyszeptał - chce być } \\
\text { Panem Bogiem. (128) }\end{array}$ & $\begin{array}{l}\text { Moja żona... - wyszeptał - } \\
\text { chce być jak dobry Bóg. }\end{array}$ \\
\hline
\end{tabular}

\section{Literatura}

\section{Teksty źródłowe:}

Grass, G., 1995, Turbot, tłum. S. Błaut, Gdańsk.

Grimm, J. i W., 1857, Kinder- und Hausmärchen, Göttingen.

Grimm, J. i W., 1982, Baśnie braci Grimm (Baśnie domowe i dziecięce zebrane przez braci Grimm), tłum. E. Bielicka, M. Tarnowski, Warszawa.

Grimm, J. i W., 2009, Baśnie, tłum. E. Pieciul-Karmińska, Poznań.

Grimm, J. i W., 2010, Baśnie dla dzieci i dla domu, tłum. E. Pieciul-Karmińska, Poznań.

Grimm, J. i W., 2012, Wszystkie baśnie i legendy, tłum. R. Skiba, Warszawa.

Grimm, J. i W., 2014, Wszystkie baśnie i legendy (wydanie drugie, poprawione), tłum. R. Skiba, Warszawa.

Puszkin, A., 1979, Bajka o rybaku i rybce, tłum. J. Tuwim, Warszawa.

\section{Literatura sekundarna}

Ewers, H.-H., 2012, „»Sie nähren unmittelbar, wie der Honig, süß und sät- 
tigend, ohne irdische Schwere...« Vom unaufhaltsamen Aufstieg der Grimm'schen Märchenideals im Biedermeier", [w:] Das Wissenschaftsmagazin Forschung Frankfurt, Frankfurt a. Main, s. 38-43.

Janion, M., 1995, „Mężczyzna, kobieta i dzieje”, [w:] Grass, G., Turbot, tłum. S. Błaut, Gdańsk, s. 7-23.

Krysztofiak, M., 1999, Przekład literacki a translatologia, Poznań.

Krysztofiak, M., 2011, Translatologiczna teoria i pragmatyka przekładu artystycznego, Poznań.

Martus, S., 2013, Die Brüder Grimm. Eine Biographie, Reinbek bei Hamburg.

Pieciul-Karmińska, E., 2013a, „Geneza baśni braci Grimm a ich przekład na język polski”, [w:] Scripta Manent - Res nova, S. Puppel, T. Tomaszkiewicz (red.), Poznań, s. 105-115.

Pieciul-Karmińska, E., 2013b, „»Niebieska broda«”, czyli dlaczego nie należy tłumaczyć baśni braci Grimm z języka rosyjskiego", [w:] Język - Komunikacja - Informacja, t. 8, Poznań, s. 58-77.

Rölleke, H., 2004, Die Märchen der Brüder Grimm. Eine Einführung, Stuttgart.

Rölleke, H., 2011, Die wahren Märchen der Brüder Grimm und wer sie ihnen erzählte, Frankfurt am Main.

Schreiber, M., 1993, Übersetzung und Bearbeitung, Tübingen.

Staniów, B., 2014, „Grimms' Fairy Tales in Poland. The analysis of publishing production in the years 1895-2011", [w:] Studia ad Bibliothecarum Scientiam Pertinentia XII, Kraków, s. 5-18.

\section{On the significance of the tale "Von dem Fischer un syner Fru" (About the Fisherman and his Wife) for the "Children's and Household Tales" by Brothers Grimm and its Polish translations}

\section{Summary}

The tale Von dem Fischer un syner Fru (About the Fisherman and His Wife) has a specific significance for the Children's and Household Tales by Brothers Grimm who regarded this one tale as a pattern for the style and content of their entire tale collection and as an embodiment of the authentic folk tale (German: Volksmärchen). However, the tale About the Fisherman and His Wife reveals also features of a literary fairytale (German: Kunstmärchen) due to Philipp Otto Runge (1877-1810), a painter and folk tale collector, who was the first one to capture the text in a written form. This double nature of the original tale makes it interesting to investigate the two existing Polish translations (by Marceli Tarnowski and by Eliza Pieciul-Karmińska) taking into account the most important features of the original text (the designation of the fish, 
the name of the fisherman's wife, the colour theory by Runge and the allusion to the Book of Genesis). The conclusions drawn from the comparative analysis can give an important insight into the reception of the entire tale collection by Brothers Grimm in Poland. It can be proved that ignoring stylistic details in translation can be to the detriment of the entire ideological message of the text. The postscript of the article contains a short characteristics of another Polish translation done via a third language (Russian), therefore containing characteristic omissions and modifications of the original text.

Keywords: tales of Brothers Grimm, translation of tales, translation series

\section{(c) $($ i) $\Theta$}

